\title{
Should e-Payment Trust be e-Commerce Implemented as a Consumer Satisfaction Factor?
}

\author{
Sabar Sutia ${ }^{1}$, Mochammad Fahlevi ${ }^{2 *}$, Mohamad Saparudin ${ }^{1}$, Dasih Irma ${ }^{1}$, Sari Maemunah ${ }^{1}$ \\ ${ }^{1}$ Management Department, Kusuma Negara Business School, Jakarta, Indonesia \\ ${ }^{2}$ Management Department, BINUS Online Learning, Bina Nusantara University, Jakarta, Indonesia \\ 11480
}

\begin{abstract}
Consumer trust related to payment is an essential topic in several studies of online shopping. Consumers are very concerned about security in transactions including when making cashless payments. This study uses a non-parametric test using a SmartPLS with a sample of 243 respondents. The results of this study provide information that E-payment trust is an important factor for consumer satisfaction in E-commerce in Indonesia. Trust related to payments is closely linked to information security and data privacy security of consumers when making transactions on E-commerce.
\end{abstract}

Keywords. E-Payment, Trust, E-Commerce, Consumer Satisfaction.

\section{Introduction}

E-commerce is a meeting place for sellers and buyers or producers and consumers who wish to make online transactions through the internet network [1]. The internet and digital development are very fast in this current era of globalization which has led to the emergence of a new business world, where everyone can communicate with others without any limitations [2]. Besides, people can make buying and selling transactions electronically with ease. The present era of globalization forces people to provide quick and simple facilities and services. Nowadays, E-commerce began to emerge which serves as a connector between consumers and producers or sellers and buyers, where it enables buying and selling transactions through internet services and making payments online using mobile banking [1]. Banking services are currently experiencing several changes with technological advancements. Banking in Indonesia is trying to keep pace with the growing fintech industry that is quite advanced in Indonesia so that it is increasingly taking on the role of banking [3].

Banking develops flexible payment services that can be used at any time such as Ebanking or mobile banking, where customers can utilize banking services without a certain time limit for 24 hours and can make non-cash payments. Even, banks have collaborated

* Corresponding author: mochammad.fahlevi@binus.ac.id 
currently with several E-commerce sites to provide online payments with multiple layers of security, particularly for international cross-currency transactions [4]. Banking services also help E-commerce in making transactions. Therefore, to improve the convenience of payment services in online transactions, E-commerce needs to intensify cooperation with banks. It is to enable the convenience for consumers in making payments with many options of online payment.

The development and utilization of technology are growing rapidly beginning from increasingly sophisticated computers and smartphones that are used continually to experience changes and improvements in terms of technology [5]. At the beginning of their presence, computers and the internet were only used to market the company's products and services. However, it has changed a lot now, especially in terms of the trade such as E-trade and noncash payments made with several advanced devices such as E-banking and mobile banking. [6].

Based on the background described, the main problem in this study is whether E-payment trust affects consumer satisfaction of Tokopedia E-commerce users? This study aims to determine the effect of E-payment trust on consumer satisfaction of Tokopedia E-commerce users. This research is expected to provide an understanding of the influence of E-payment design on Tokopedia E-commerce users. This research can provide information on the impact of the development and evaluation of the utilization of e-payment on consumers who use Tokopedia e-commerce. This research can determine whether the E-payment has the best innovation in gaining benefits, especially for Tokopedia E-commerce users.

E-payment system can be defined as the exchange of values between parties in business transactions through the networks of information and communication technology [7]. This payment system has emerged in the business world as more and more online stores and online transactions are made by the public. The emergence of e-commerce has made the payment system expands, providing a number of payment options to consumers as a form of service. E-commerce basically depends on non-cash payments, so it is essential for e-commerce to develop an e-payment system [7].

Online payment systems have more benefits over traditional payment systems, such as not being bound by time and space. Payments can be performed anytime and anywhere so it will be more practical for consumers to make payments online when buying something [6]. Besides, to make it easier for humans to make transactions, e-payment also helps minimize global warming since it does not need paper and what is needed in traditional transactions.

The big theory in receiving information is gained from Trust Theory. Consumer satisfaction is highly dependent on trust when making purchases as expected by consumers [8]. Online payment systems must pay attention to the security factor since it is very different from traditional payment systems [9]. The security and protection system in the E-payment system is the primary consideration for consumers to make transactions. When these two things have been fulfilled, consumers will not hesitate in making payments. All forms of risk must be avoided since it will impact on the lack of consumer confidence in the company.

Online payment is better known as E-payment, which is a payment made in a transaction that transfers a certain amount of money in real-time [10]. Companies must collaborate with banks or financial companies that provide payment services online or E-payment.

Consumer satisfaction compares the goods or services purchased in line with their expectations so that it will cause a happy feeling because it is in accordance with their expectations [11]. Trust has been identified as the main driving factor for customer loyalty [12]. Consumer satisfaction has a high impact on repurchases and consumer loyalty to a product [13].

In the context of this study, satisfaction refers to the post-choice and affective evaluative responses of users to their experience with mobile payment; besides, satisfaction is captured as positive feelings (satisfaction), indifference, or negative feelings (dissatisfaction) [14]. 
Referred to satisfaction as a global evaluation of a trustworthy relationship [15]. Besides, according to the extended theory of reasoned action proposed by [16], we know that trust can influence attitude. From the explanation above, we argue that user trust can affect their attitude, namely satisfaction. In E-payment services, trust refers to the user's perception of service provider attributes, including the ability, integrity, and virtue of the provider. [17]. When users consider electronic payment service providers to be reliable and generally trustworthy, they will be satisfied with electronic payments and positively evaluate the service. If users don't trust electronic payments, they may not be satisfied with the service and they generate a negative evaluation. The relation between trust and satisfaction is also supported by previous research [18].

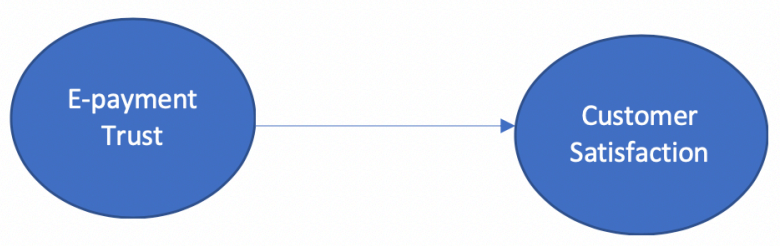

Fig. 1. Research Framework

Ho: There is no significant effect between E-payment trust toward customer satisfaction toward E-commerce.

Ha: There is a significant effect between E-payment trust toward customer satisfaction toward E-commerce.

\section{Methodology}

The type of this research is explanative research using quantitative approach. Based on [19], research according to the level of explanation is research that intends to explain the position of the variables studied and the relation between one variable with another variable. The population is the total number of objects that want to be studied and it consists of individuals who have different characters and are considered to contain the information needed [20]. The object is called as unit of analysis. It can represent people, institutions or things. The population in this research was the people of West Jakarta who were over 18 years and those who knew and had shopped at Tokopedia E-commerce and use E-payment as a payment transaction tool in the Tokopedia E-commerce marketplace. The sample in this research used the Slovin formula in determining the number of samples and found total of 243 respondents were sampled in this research. This research used data analysis methods and SmartPLS software, variant-based structural model (SEM) which can simultaneously test measurement models as well as structural model testing. The measurement model was used to test the validity and reliability, while the structural model was used to test the causality (hypothesis testing with predictive models) [21]. 


\section{Result and Discussion}

In this research distributed questionnaire to 243 respondents. The majority of respondents, $58.1 \%$ were under 20 years. The occupation of $74.3 \%$ respondents were as students and the rest were as employees, entrepreneurs, and others. $54.6 \%$ of the respondents thought that the use of E-payment was very helpful while shopping online and $61.3 \%$ of the respondents were satisfied with the E-payment interface.

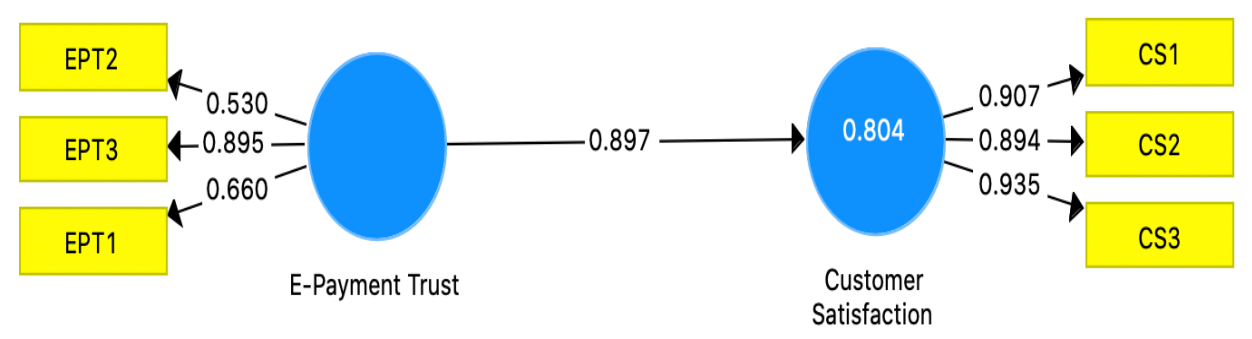

Fig. 2. R-Square

It is known that R-Square is high of 0.804 or $80.4 \%$. It means that the exogenous variable of this research, the E-payment trust, has the power as a predictor of endogenous variable. It is a consumer satisfaction of $80.4 \%$. This result is a high enough number in a research. Path coefficient indicates the direct effect of exogenous determined as the cause of endogenous which is determined as a result. If the model is recursive, path coefficients can be expressed using simple correlations or multiple regression. The actual path coefficient is the standardized regression coefficient. The magnitude of the path coefficient shows the direct effect of the exogenous variable on endogenous. The picture above also provides information that the E-payment trust has a path coefficient of 0.897 on customer satisfaction.

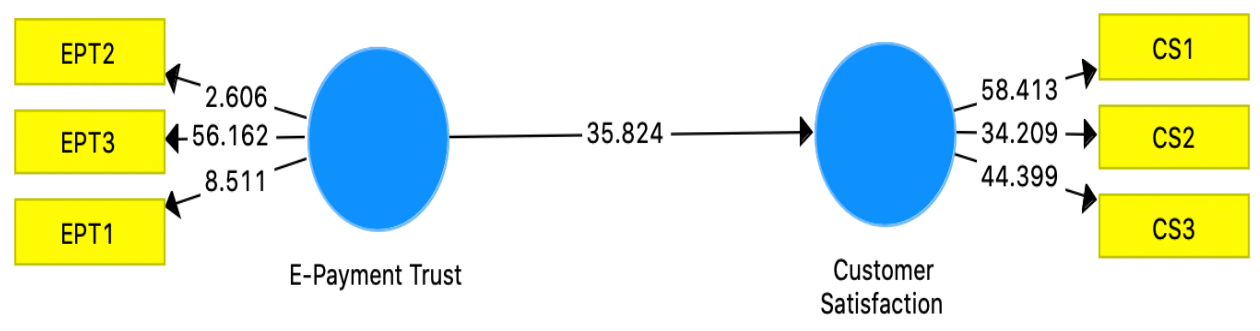

Fig. 3. Path Analysis

The summary of the figure above can be seen in the table below:

Table 1. Path Coefficient

\begin{tabular}{llll}
\hline Path Coefficient & $\begin{array}{l}\text { Standard } \\
\text { Deviation }\end{array}$ & T-Statistics & P-Value \\
\hline E-Payment Trust $\rightarrow$ Customer satisfaction & 0.025 & 35.824 & 0.000 \\
\hline
\end{tabular}


The result above shows that $\mathrm{P}-\mathrm{V}$ alue is $0.000<0.05$. Thus, in can be considered that $\mathrm{H} 0$ is rejected or alternative hypothesis in this research is accepted. It means that there is a significant influence between E-payment trust on customer satisfaction.

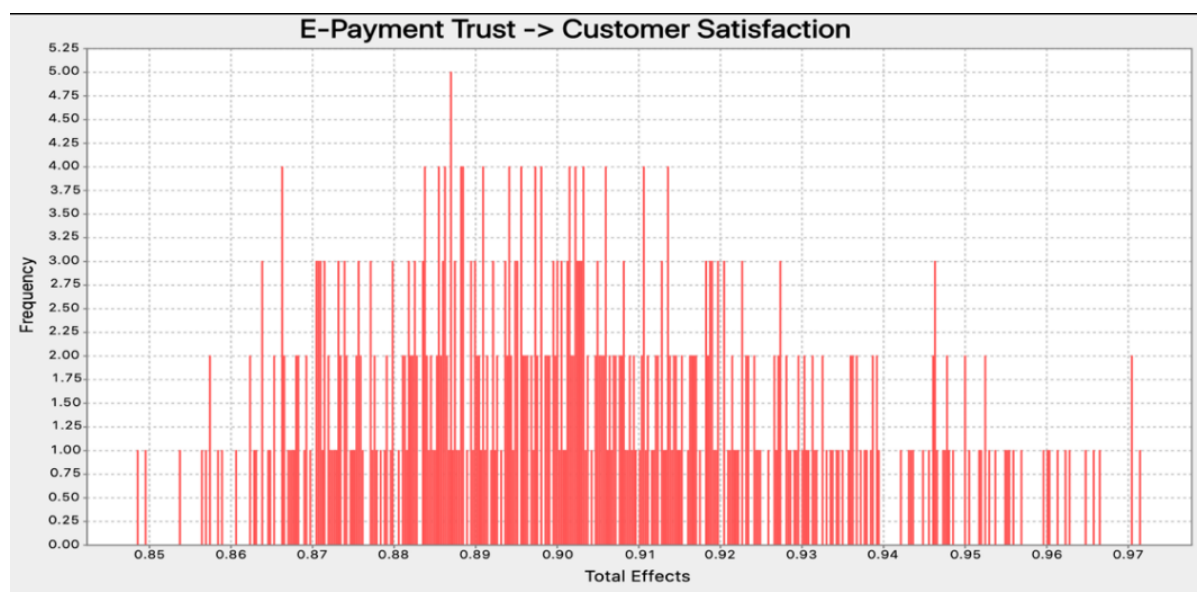

Fig. 4. Histogram of Total Effects

Output Bootstrap also includes histogram that shows dispersion of estimated values throughout the iteration. For example, the histogram above shows the distribution of path loading coefficients for the model path from trust E-payment to customer satisfaction. This is a graphical way to display the same information as contained in the confidence interval. The results of histogram above show that the exogenous effect on endogenous is quite high.

The results of the research give information that E-payment trust is one of the important factors for consumer satisfaction in E-commerce in Indonesia. Trust related to payments is closely related to information and data privacy securities of consumers while making transactions on E-commerce. The results of this research are in accordance with previous studies conducted by [6]. With the existence of this E-payment system, it enables to make transactions easier than using cash. Besides increasing payment efficiency, it increases customer loyalty and further increasing effectiveness and time efficiency.

The effect of trust and satisfaction relates closely to previous research that has the same result as the research conducted by $[18,22]$. When users consider electronic payment service providers to be reliable and generally trustworthy, they will be satisfied with electronic payments and positively evaluate these services. If users don't trust electronic payments, they may not be satisfied with the service and produce a negative evaluation.

The results of the research show that payment factor of E-payment in each E-commerce in Indonesia needs to be paid attention and developed well at the level of security or cashless payment option facilities that facilitate consumers to make transactions online. Thus, customer satisfaction will increase this will be related to repurchase and loyalty from consumers to E-commerce as explained by [11] that the satisfaction variable has a positive impact toward the company.

\section{Conclusion}

The results of the research give information that E-payment trust is an important factor for consumer satisfaction in E-commerce in Indonesia. The results of this are inline with previous research conducted by [6]. Online payment systems help in increasing customer satisfaction and loyalty because it is more efficient than traditional payment ones. The results of this 
research explain that the payment factor in the form of E-payment in every E-commerce in Indonesia needs to be paid attention and developed both at the level of security or cashless payment option facilities that make it easy for consumers to conduct transactions online.

\section{References}

1. Suwarni, R. Noviantoro, M. Fahlevi, and M. N. Abdi, Int. J. Control Autom. 13, 785 (2020)

2. S. Sutia, R. Riadi, and M. Fahlevi, Int. J. Supply Chain Manag. 9, 86 (2020)

3. Kasbuntoro, D. Irma, S. Maemunah, I. Mahfud, M. Fahlevi, and R. D. Parashakti, Int. J. Control Autom. 13, 439 (2020)

4. M. Fahlevi, M. Saparudin, S. Maemunah, D. Irma, and M. Ekhsan, in 4th Int. Conf. Energy, Environ. Epidemiol. Inf. Syst. (ICENIS 2019) (EDP Sciences, Semarang, 2019), pp. $1-5$

5. S. Sutia, S. Adha, and M. Fahlevi, in 4th Int. Conf. Energy, Environ. Epidemiol. Inf. Syst. (ICENIS 2019) (EDP Sciences, Semarang, 2019), pp. 1-5

6. D. W. Putri and Z. Baridwan, J. Ilm. Mhs. FEB 3, (2014)

7. C. K. Ayo and W. I. Ukpere, African J. Bus. Manag. 4, 1753 (2010)

8. S. Y. Yousafzai, J. G. Pallister, and G. R. Foxall, Technovation 23, 847 (2003)

9. K. Linck, K. Pousttchi, and D. G. Wiedemann, in 14th Eur. Conf. Inf. Syst. (University of Augsburg, Goteborg, 2007), pp. 1-11

10. C. Kim, W. Tao, N. Shin, and K. S. Kim, Electron. Commer. Res. Appl. 9, 84 (2010)

11. P. Kotler and K. L. Keller, MarkKotler, P., \& Keller, K. L. (2016). Marketing Management. Global Edition (Vol. 15E) (2016)

12. M. Horppu, O. Kuivalainen, A. Tarkiainen, and H. K. Ellonen, J. Prod. Brand Manag. 17, 403 (2008)

13. S. Sutia, M. Fahlevi, Rita, A. S. Rabiah, and S. Adha, Int. J. Psychosoc. Rehabil. 24, $6628(2020)$

14. X. Cao, L. Yu, Z. Liu, M. Gong, and L. Adeel, Internet Res. 28, 456 (2018)

15. F. R. Dwyer, P. H. Schurr, and S. Oh, J. Mark. 51, 11 (1987)

16. H. H. Lin and Y. S. Wang, Inf. Manag. 43, 271 (2006)

17. D. H. McKnight, V. Choudhury, and C. Kacmar, Inf. Syst. Res. 13, 334 (2002)

18. I. Elbeltagi and G. Agag, Internet Res. 26, 288 (2016)

19. M. Saunders, P. Lewis, and A. Thornhill, Research Methods for Business Students, 5th ed. (Prentice Hall, London, 2009)

20. R. B. Darlington and A. F. Hayes, Regression Analysis and Linear Models (The Guilford Press, New York, 2017)

21. J. F. Hair, G. T. M. Hult, C. M. Ringle, and M. Sarstedt, A Primer on Partial Least Squares Structural Equation Modeling (PLS-SEM), 2nd ed. (Sage, California, 2017)

22. K. L. Gwebu, J. Wang, and L. Guo, Decis. Support Syst. 67, 66 (2014) 